\begin{tabular}{|c|l|}
\hline Title & Characteristics of try psin from the pyloric ceca of wall leye pollock (Theragra chal cogramma) \\
\hline Author(s) & Kishimura, Hideki; Klomklao, Sappasith; Benjakul, Soottawat; Chun, By ung-Soo \\
\hline Citation & $\begin{array}{l}\text { Food Chemistry, 106(1), 194199 } 190 \\
\text { https://doi.org/10.1016j.foodchem.2007.05.056 }\end{array}$ \\
\hline Issue Date & 2008-01-01 \\
\hline Doc URL & http://hdl.handle.net/2115/30273 \\
\hline Type & article (author version) \\
\hline File Information & FC106-1.pdf \\
\hline
\end{tabular}

Instructions for use 


\section{Characteristics of trypsin from the pyloric ceca of walleye pollock (Theragra chalcogramma)}

Hideki Kishimura $^{a^{*}}$, Sappasith Klomklao ${ }^{b}$, Soottawat Benjakul ${ }^{\mathrm{c}}$, Byung-Soo Chun ${ }^{\mathrm{d}}$

${ }^{a}$ Research Faculty of Fisheries Sciences, Hokkaido University,

Hakodate, Hokkaido 041-8611, Japan

${ }^{\mathrm{b}}$ Department of Food Science and Technology, Faculty of Technology and Community Development, Thaksin University, Phattalung Campus, Phattalung 93110, Thailand

${ }^{\mathrm{c}}$ Department of Food Technology, Faculty of Agro-Industry, Prince of Songkla University, Hat Yai, Songkhla 90112, Thailand

${ }^{\mathrm{d}}$ Faculty of Food Science and Biotechnology, Pukyong National University, Busan 608-737, Korea

*Corresponding author: Tel./Fax.: +81-138-40-5519; E-mail: kishi@,fish.hokudai.ac.jp 


\section{Abstract}

Trypsin was purified from the pyloric ceca of walleye pollock (Theragra chalcogramma) by gel filtration on Sephacryl S-200 and Sephadex G-50. The final enzyme preparation was nearly homogeneous in sodium dodecyl sulfate-polyacrylamide gel electrophoresis (SDS-PAGE) and the molecular mass of the enzyme was estimated to be $24 \mathrm{kDa}$ by SDS-PAGE. Trypsin activity was effectively inhibited by serine protease inhibitors, such as soybean trypsin inhibitor and TLCK. Trypsin had maximal activities at around $\mathrm{pH} 8.0$ and $50{ }^{\circ} \mathrm{C}$ for the hydrolysis of $N^{\alpha}$-p-tosyl-Larginine methyl ester hydrochloride. Trypsin was unstable above $30{ }^{\circ} \mathrm{C}$ and below $\mathrm{pH} 5.0$, and was stabilized by calcium ions. Walleye pollock trypsin was more thermo unstable than trypsin from the Temperate Zone fish and Tropical Zone fish. The $N$-terminal amino acid sequence of the trypsin, IVGGYECTKHSQAHQVSLNS, was found, and the sequencial identity between the walleye pollock trypsin and Frigid Zone fish trypsin was higher (85-100\%) than with Temperate Zone fish trypsin (75-90\%), Tropical Zone fish trypsin (75-85\%), or mammalian trypsin (60$65 \%)$.

Keywords: Walleye pollock; Theragra chalcogramma; Pyloric caecum; Trypsin; $N$-terminal amino acid sequence; Thermo stability; Frigid Zone fish 


\section{Introduction}

The development of the fisheries industry will depend on the effective utilization of the available raw materials. Fish viscera are non-edible parts produced in large quantities by the fisheries industry and represent as waste or pollution. These materials, however, are rich potential sources of various enzymes that may have some unique properties of interest for both basic research and industrial applications (Simpson \& Haard, 1999).

Fishe are poikilothermic, so their survival in cold waters required adaptation of their enzyme activities to the low temperatures of their habitats. Enzymes from cold adapted fish species thus often have higher emzymatic activities at low temperatures than their counterparts from warm-blooded animals (Asgeirsson, Fox, \& Bjarnason, 1989; Kristjansson, 1991). High activity of fish enzymes at low temperatures may be interesting for several industrial applications of enzymes, such as in certain food processing operations that require low processing temperatures. Furthermore, relatively lower thermal stability, often observed with fish enzymes, may also be beneficial in such applications as the enzymes can be inactivated more readily, with less heat treatment, when desired in a given process (Simpson \& Haard, 1987).

Walleye pollock (Theragra chalcogramma) is one of the important fish-catches of Japan and its muscle is used almost entirely for "surimi" production. However, postmortem walleye pollock autolyzes very quickly due to enzymes leaking from the digestive organs and its viscera are largely underutilized and are discarded as waste. It is reported that Monterey sardine (Sardinops sagax caerulea) (Castillo-Yanez, Pacheco-Aguilar, Garcia-Carreno, \& Toro, 2005), true sardine (Sardinops melanostictus) (Kishimura, Hayashi, Miyashita, \& Nonami, 2006a), and spotted mackerel (Scomber australasicus) (Kishimura, Tokuda, Klomklao, Benjakul, \& Ando, 2006b) are also susceptible to abdominal autolytic degradation after death, and they isolated and characterized trypsin in its viscera. Trypsin (EC 3.4.21.4), which is detected in the pyloric ceca and intestine of 
fish, is one of the main digestive proteases. It is a member of a large family of serine proteases and cleaves the peptide bond on the carboxyl side of arginine and lysine (Klomklao, Benjakul, Visessanguan, Kishimura,\& Simpson, 2007). In this study, we purified trypsin from the pyloric ceca of walleye pollock and compared its characteristics with those of other fish and porcine pancreatic trypsins.

\section{Materials and methods}

\subsection{Materials}

The walleye pollock (T. chalcogramma) was caught off Hakodate, Hokkaido Prefecture, Japan. Sephacryl S-200 and Sephadex G-50 were purchased from Pharmacia Biotech (Uppsala, Sweden). $\quad N^{\alpha}$-p-Tosyl-L-arginine methyl ester hydrochloride (TAME) and porcine pancreatic trypsin were purchased from Wako Pure Chemicals (Osaka, Japan).

\subsection{Preparation of crude enzyme}

Defatted powder of the pyloric ceca of walleye pollock was prepared by the same method of Kishimura \& Hayashi (2002). Trypsin was extracted by stirring from the defatted powder in 50 volumes of $10 \mathrm{mM}$ Tris- $\mathrm{HCl}$ buffer ( $\mathrm{pH} \mathrm{8.0)}$ containing $1 \mathrm{mM} \mathrm{CaCl}_{2}$ at $5{ }^{\circ} \mathrm{C}$ for $3 \mathrm{~h}$. The extract was centrifuged (H-2000B, Kokusan, Tokyo, Japan) at $10,000 \times \mathrm{g}$ for $10 \mathrm{~min}$, and then the supernatant was lyophilized and used as crude trypsin.

\subsection{Trypsin Purification}


The crude trypsin of walleye pollock was applied to a column of Sephacryl S-200 $(3.9 \times 64$ $\mathrm{cm}$ ) pre-equilibrated with $50 \mathrm{mM}$ Tris- $\mathrm{HCl}$ buffer $(\mathrm{pH} 8.0)$ containing $1 \mathrm{mM} \mathrm{CaCl}_{2}$ and the proteins were eluted with the same buffer at a flow rate of $0.5 \mathrm{ml} / \mathrm{min}$ at $4{ }^{\circ} \mathrm{C}$. The main trypsin fractions were concentrated by lyophilization and then dissolved in distilled water prior to size exclusion chromatography. The sample was chromatographed on a Sephadex G-50 column $(3.9 \times 64 \mathrm{~cm})$ previously equilibrated with $10 \mathrm{mM}$ Tris- $\mathrm{HCl}$ buffer $(\mathrm{pH} 8.0)$ containing $1 \mathrm{mM} \mathrm{CaCl} \mathrm{Cl}_{2}$ and the proteins were eluted with the same buffer at a flow rate of $0.5 \mathrm{ml} / \mathrm{min}$. The fractions with TAME activity were pooled and used for further studies.

\subsection{Assay for trypsin activity}

Trypsin activity was measured by the method of Hummel (1959) using TAME as a substrate. One unit of enzyme activity was defined as the amount of the enzyme hydrolyzing one micromole of TAME in a minute. The $\mathrm{pH}$ dependencies of the enzyme were determined in $50 \mathrm{mM}$ buffer solutions [acetic acid-sodium acetate ( $\mathrm{pH}$ 4.0-7.0), Tris- $\mathrm{HCl}(\mathrm{pH}$ 7.0-9.0), and glycine- $\mathrm{NaOH}$ (pH 9.0-11.0)] at $30{ }^{\circ} \mathrm{C}$. The temperature dependencies of the enzyme were determined in $50 \mathrm{mM}$ Tris- $\mathrm{HCl}$ buffer $\mathrm{pH} 8.0$ and at various temperatures. The effects of temperature and $\mathrm{pH}$ on the stability of the enzyme were found by incubating the enzyme in $50 \mathrm{mM}$ Tris- $\mathrm{HCl}$ buffer $\mathrm{pH} 8.0$ for $15 \mathrm{~min}$ at a range of $20-70{ }^{\circ} \mathrm{C}$ and by incubating the enzyme at $30{ }^{\circ} \mathrm{C}$ for $30 \mathrm{~min}$ at a range of $\mathrm{pH}$ 4.0-11.0 (50 $\mathrm{mM}$ buffer solutions), respectively. The effect of $\mathrm{CaCl}_{2}$ on the activity of the enzyme was found by incubating the enzyme at $30{ }^{\circ} \mathrm{C}$ and in $50 \mathrm{mM}$ Tris- $\mathrm{HCl}$ buffer $\mathrm{pH} 8.0$ with the presence of $10 \mathrm{mM}$ ethylenediaminetetraacetic acid (EDTA) or $10 \mathrm{mM} \mathrm{CaCl}_{2}$.

\subsection{Polyacrylamide gel electrophoresis}


Sodium dodecyl sulfate-polyacrylamide gel electrophoresis (SDS-PAGE) was carried out using a $0.1 \%$ SDS-12.5\% polyacrylamide slab-gel by the method of Laemmli (1970). The gel was stained with $0.1 \%$ Coomassie Brilliant Blue R-250 in $50 \%$ methanol-7\% acetic acid and the background of the gel was destained with $7 \%$ acetic acid.

\subsection{Analysis of amino acid sequence}

To analyze the $\mathrm{N}$-terminal sequence, the purified enzyme was electroblotted on to polyvinylidenedifluoride (PVDF) membrane (Mini ProBlott Membranes, Applied Biosystems, CA, USA) after SDS-PAGE. The amino acid sequence of the enzyme was analyzed by using a protein sequencer, Procise 492 (Perkin Elmer, Foster City, CA, USA).

\subsection{Protein determination}

The protein concentration was determined by the method of Lowry, Rosebrough, Farr, \& Randall (1951) using bovine serum albumin as a standard.

\section{Results and discussion}

In this study, trypsin was purified from the pyloric ceca of walleye pollock by gel filtration on Sephacryl S-200 and Sephadex G-50, and the purity was increased to 83 fold with approximately $28 \%$ yield (Table 1). The molecular weight of the trypsin was estimated as approximately $24 \mathrm{kDa}$ using SDS-PAGE (Fig. 1) similar to those of mammalian pancreatic, Atlantic cod (Gudmundsdottir, Gudmundsdottir, Oskarsson, Bjarnason, Eakin, \& Craik, 1993), true sardine (Kishimura et al., 
2006a), arabesque greenling (Kishimura et al., 2006a), jacopever (Kishimura, Tokuda, Yabe, Klomklao, Benjakul, \& Ando, 2007), elkhorn sculpin (Kishimura et al., 2007) trypsins, which were smaller than trypsins of capelin (28 kDa) (Hjelmeland \& Raa, 1982), catfish (26 kDa) (Yoshinaka, Suzuki, Sato, \& Ikeda, 1983), anchovy (27-28 kDa) (Martinez, Olsen, \& Serra, 1988), rainbow trout (25.7 kDa) (Kristjansson, 1991), and Monterey sardine (25 kDa) (Castillo-Yanez et al., 2005). The effects of various proteinase inhibitors on the activity of the walleye pollock trypsin were determined (Table 2). The trypsin was strongly inhibited by serine proteinase inhibitor, such as soybean trypsin inhibitor and TLCK $(82-91 \%)$. While, specific inhibitors of cysteine proteinase (E-64, $N$-ethylmaleimide, iodoacetic acid), chymotrypsin (TPCK), aspartic proteinase (pepstatin A), and metallo proteinase (EDTA) had almost no inhibitory effect on the activities of walleye pollock trypsin. These results for molecular weight and effects of inhibitors confirmed that the purified enzyme was serine proteinase, most likely trypsin.

The effect of $\mathrm{CaCl}_{2}$ on the stability of the walleye pollock trypsin was determined in the presence of $10 \mathrm{mM}$ EDTA or $10 \mathrm{mM} \mathrm{CaCl}_{2}$. The trypsin was stabilized by calcium ion (Fig. 2a) similar to porcine pancreatic trypsin (Fig. 2b). Two calcium binding sites are in bovine trypsinogen (Kossiakoff, 1977). The primary site, with a higher affinity for calcium ions, is common in trypsinogen and trypsin, and the secondary site is only in the zymogen. Occupancy of the primary calcium binding site stabilizes the protein toward thermal denaturation or autolysis. The walleye pollock trypsin was stabilized by calcium ion from thermal denaturation. This finding suggests that the walleye pollock trypsin possesses the primary calcium binding site like mammalian pancreatic trypsin and other fish trypsins (Male, Lorens, Smalas, \& Torrissen, 1995; Genicot, Rentier-Delrue, Edwards, Vanbeeumen, \& Gerday, 1996; Kishimura et al., 2006a, 2006b; Kishimura, Tokuda, Klomklao, Benjakul, \& Ando, 2006c; Kishimura et al., 2007).

Fig. 3a shows the $\mathrm{pH}$ dependence of the walleye pollock trypsin. The enzyme hydrolyzed the TAME effectively at alkaline $\mathrm{pH}$ with an optimum activity at $\mathrm{pH} 8.0$ similar to those of porcine 
pancreatic trypsin (Fig. 3b) and other fish trypsins (Hjelmeland \& Raa, 1982; Simpson \& Haard, 1984; Yoshinaka, Sato, Suzuki, and Ikeda, 1984; Martinez et al., 1988; Asgeirsson et al., 1989; Castillo-Yanez et al., 2005; Kishimura, Hayashi, Miyashita, \& Nonami, 2005; Kishimura et al., 2006a, 2006b, 2006c, 2007). For pH stability, the enzyme was stable between pH 6.0 and 11.0, but it was unstable below pH 6.0 (Fig. 4a). The property of the pH stability of the walleye pollock trypsin was similar to those of other fish trypsins (Martinez et al., 1988; Asgeirsson et al., 1989; Kristjansson, 1991; Kishimura et al., 2005, 2006a, 2006b, 2006c, 2007), but not to porcine pancreatic trypsin (Fig. 4b).

The effects of various temperatures on the activity of trypsin from walleye pollock are shown in Fig. 5a. Optimum temperature of the trypsin was $50{ }^{\circ} \mathrm{C}$, which was lower than that of porcine pancreatic trypsin $\left(60-70{ }^{\circ} \mathrm{C}\right.$; Fig. 5b). The walleye pollock is a Frigid Zone fish and its trypsin had an optimum temperature of $50{ }^{\circ} \mathrm{C}$ (Fig. 5a) similar to those of other trypsins from Frigid Zone fish, such as arabesque greenling, brown hakeling, and elkhorn sculpin (Kishimura et al., 2006a, 2006b, 2007). Optimum temperature of the walleye pollock trypsin was lower than those of porcine pancreatic trypsin $\left(60-70{ }^{\circ} \mathrm{C}\right.$; Fig. $\left.5 \mathrm{~b}\right)$, Temperate Zone fish trypsin $\left(60^{\circ} \mathrm{C}\right)$ (Kishimura et al., 2005, 2006a, 2006b, 2006c, 2007), and Tropical Zone fish trypsin $\left(55-65{ }^{\circ} \mathrm{C}\right)$ (Klomklao, Benjakul, Visessanguan, Kishimura, Simpson, \& Saeki, 2006a; Klomklao, Benjakul, Visessanguan, Kishimura, \& Simpson, 2006b; Klomklao et al., 2007). Fig. 6a shows the temperature stability of the walleye pollock trypsin. The trypsin was stable below $30{ }^{\circ} \mathrm{C}$, but its activity quickly fell above $40{ }^{\circ} \mathrm{C}$. Similar to those of other trypsins from Frigid Zone fish (Kishimura et al., 2006a, 2006b, 2007), the temperature stability of the walleye pollock trypsin was unstable than trypsins from the Temperate Zone fish (Kishimura et al., 2005, 2006a, 2006b, 2006c, 2007), Tropical Zone fish (Klomklao et al., 2006a, 2006b, 2007), and porcine pancreas (Fig. 6b). Then, it was investigated that the relationship between habitat temperature of fish and thermo stability of the fish trypsin. As shown in Fig. 7, the relationship between habitat temperature of fish and thermo stability of the 
fish trypsin indicated strong positive correlation. This is the first result on the relationship between habitat temperature and thermo stability for the trypsin. Furthermore, the $N$-terminal amino acid sequence of the walleye pollock trypsin was also analyzed. The $N$-terminal amino acid sequence of the trypsin was determined to be IVGGYECTKHSQAHQVSLNS (Fig. 8). It was indicated that the $N$-termini of the trypsin was unblocked. The $N$-terminal amino acid sequence of the walleye pollock trypsin was aligned with the sequences of other animal trypsins. Being similar to other fish trypsins, the walleye pollock trypsin had a charged Glu residue at position 6, where Thr is most common in mammalian pancreatic trypsins (Fig. 8). Bovine pancreatic trypsin has a disulfide bond between Cys-7 and Cys-142 (Stroud, Kay, \& Dickerson, 1974), and other vertebrate trypsins also possess the Cys-7. As shown in Fig. 8, the Cys residue at position 7 was characteristically conserved in the walleye pollock trypsin. The $N$-terminal amino acid sequence of the walleye pollock trypsin was completely identical with that of cod trypsin, and the identity between the walleye pollock trypsin to Firigid Zone fish trypsin was relatively higher (85-100\%) than Temperate Zone fish trypsin (75-90 \%), Tropical Zone fish trypsin (75-85\%), and mammalian trypsin (60-65\%) (Fig. 8).

In conclusion, the walleye pollock trypsin showed a lower optimum temperature than that of porcine pancreatic trypsin and was more unstable than porcine pancreatic trypsin below $\mathrm{pH} 6.0$ and above $40{ }^{\circ} \mathrm{C}$. These results suggest that the pyloric ceca of walleye pollock could be a potential source of trypsin for certain food processing operations that require low processing temperatures, and the relatively low thermal stability of the walleye pollock trypsin may also be beneficial in such applications as the enzymes can be inactivated more readily.

\section{Acknowledgment}

The authors wish to thank Mr. T. Hirose, the Center for Instrumental Analysis, Hokkaido University, for amino acid sequence analysis. 


\section{References}

Asgeirsson, B., Fox, J.W., \& Bjarnason, J.B. (1989). Purification and characterization of trypsin from the poikilotherm Gadus morhua. European Journal of Biochemistry, 180, 85-94.

Castillo-Yanez, F.J., Pacheco-Aguilar, R.,Garcia-Carreno, F.L., \& Toro, M.A.N. (2005). Isolation and characterization of trypsin from pyloric caeca of Monterey sardine Sardinops sagax caerulea. Comparative Biochemistry and Physiology, 140B, 91-98.

Emi, M., Nakamura, Y., Ogawa, M., Yamamoto, T., Nishide, T., Mori, T., \& Matsubara, K. (1986). Cloning, characterization and nucleotide sequences of two cDNAs encoding human pancreatic trypsinogens. Gene, 41, 305-310.

Genicot, S., Rentier-Delrue, F., Edwards, D., Vanbeeumen, J., \& Gerday, C. (1996). Trypsin and trypsinogen from Antarctic fish: molecular basis of cold adaptation. Biochimica et Biophysica Acta, 1298, 45-57.

Gudmundsdottir, A., Gudmundsdottir, E., Oskarsson, S., Bjarnason, J.B., Eakin, A.K., \& Craik, C.S. (1993). Isolation and characterization of cDNAs from Atlantic cod encoding two different forms of trypsinogen. European Journal of Biochemistry, 217, 1091-1097.

Hermodson, M.A., Ericsson, L.H., Neurath, H., \& Walsh, K.A. (1973). Determination of the amino acid sequence of porcine trypsin by sequenator analysis. Biochemistry, 12, 3146-3153.

Hjelmeland, K., \& Raa, J. (1982). Characteristics of two trypsin type isozymes isolated from the Arctic fish capelin (Mallotus villosus). Comparative Biochemistry and Physiology, 71B, $557-562$.

Hummel, B.C.W. (1959). A modified spectrophotometric determination of chymotrypsin, trypsin, and thrombin. Canadian Journal of Biochemistry and Physiology, 37, 1393-1399.

Kishimura, H., \& Hayashi, K. (2002). Isolation and characteristics of trypsin from pyloric ceca of the starfish Asterina pectinifera. Comparative Biochemistry and Physiology, 132B, 485- 
490.

Kishimura, H., Hayashi, K., Miyashita, Y., \& Nonami, Y. (2005). Characteristics of two trypsin isozymes from the viscera of Japanese anchovy (Engraulis japonica). Journal of Food Biochemistry, 29, 459-469.

Kishimura, H., Hayashi, K., Miyashita, Y., \& Nonami, Y. (2006a). Characteristics of trypsin from the viscera of true sardine (Sardinops melanostictus) and the pyloric ceca of arabesque greenling (Pleuroprammus azonus). Food Chemistry, 97, 65-70.

Kishimura, H., Tokuda, Y., Klomklao, S., Benjakul, S., \& Ando, S. (2006b). Enzymatic characteristics of trypsin from pyloric ceca of spotted mackerel (Scomber australasicus). Journal of Food Biochemistry, 30, 466-477.

Kishimura, H., Tokuda, Y., Klomklao, S., Benjakul, S., \& Ando, S. (2006c). Comparative study of enzymatic characteristics of trypsins from the pyloric ceca of yellow tail (Seriola quinqueradiata) and brown hakeling (Physiculus japonicus). Journal of Food Biochemistry, $30,521-534$.

Kishimura, H., Tokuda, Y., Yabe, M., Klomklao, S., Benjakul, S., \& Ando, S. (2007). Trypsins from the pyloric ceca of jacopever (Sebastes schlegelii) and elkhorn sculpin (Alcichthys alcicornis): isolation and characterization. Food Chemistry, 100, 1490-1495.

Klomklao, S., Benjakul, S., Visessanguan, W., Kishimura, H., Simpson, B. K., \& Saeki, H. (2006a). Trypsins from yellowfin tuna (Thunnus albacores) spleen: purification and characterization. Comparative Biochemistry and Physiology, 144B, 47-56.

Klomklao, S., Benjakul, S., Visessanguan, W., Kishimura, H., \& Simpson, B. K. (2006b). Purification and characterization of trypsin from the spleen of tongol tuna (Thunnus tonggol). Journal of Agricultural and Food Chemistry, 54, 5617-5622.

Klomklao, S., Benjakul, S., Visessanguan, W., Kishimura, H., \& Simpson, B. K. (2007). Purification and characterization of trypsins from the spleen of skipjack tuna (Katsuwonus 
pelamis). Food Chemistry, 100, 1580-1589.

Kossiakoff, A.A., Chambers, J.L., Kay, L.M., \& Stroud, R.M. (1977). Structure of bovine trypsinogen at 1.9A resolution. Biochemistry, 16, 654-664.

Kristjansson, M.M. (1991). Purification and characterization of trypsin from the pyloric caeca of rainbow trout (Oncorhynchus mykiss). Journal of Agricultural and Food Chemistry, 39, $1738-1742$.

Laemmli, U.K. (1970). Cleavage of structural proteins during the assembly of the head of bacteriophage T4. Nature, 227, 680-685.

Lowry, O.H., Rosebrough, N.J., Farr, A.L., \& Randall, R.J. (1951). Protein measurement with the Folin phenol reagent. Journal of Biologycal Chemistry, 193, 265-273.

Martinez, A., Olsen, R.L., \& Serra, J.L. (1988). Purification and characterization of two trypsin-like enzymes from the digestive tract of anchovy Engraulis encrasicholus. Comparative Biochemistry and Physiology, 91B, 677-684.

Male, R., Lorens, L.B., Smalas, A.O., \& Torrissen, K.R. (1995). Molecular cloning and characterization of anionic and cationic variants of trypsin from Atlantic salmon. European Journal of Biochemistry, 232, 677-685.

Simpson, B.K., \& Haard N.F. (1984). Trypsin from Greenland cod, Gadus ogac. Isolation and comparative properties. Comparative Biochemistry and Physiology, 79B, 613-622.

Simpson, B.K., \& Haard N.F. (1987). Cold-adapted enzymes from fish. In D. Knorr (Ed.), Food Biotechnology, (pp. 495-528). New York: Marcel Dekker.

Simpson, B.K., \& Haard N.F. (1999). Marine enzymes. In F.J. Francis (Ed.), Encyclopedia of Food Science and Technology, Second edition, Vol. 3. (pp. 1525-1534). New York: John Wiley and Sons Inc.

Stroud, R.M., Kay, L.M., \& Dickerson, R.E. (1974). The structure of bovine trypsin: electron density maps of the inhibited enzyme at $5 \AA$ and $2.7 \AA$ resolution. Journal of 
Molecular Biology, 83, 185-208.

Walsch, K.A. (1970). Trypsinogens and trypsins of various species. Methds in Enzymology, 19, 4163.

Yoshinaka, R., Suzuki, T., Sato, M., \& Ikeda, S. (1983). Purification and some properties of anionic trypsin from the catfish pancreas. Bulletin of Japanese Society of Scientific Fisheries, 49, 207-212.

Yoshinaka, R., Sato, M., Suzuki, T., \& Ikeda, S. (1984). Enzymatic characterization of anionic trypsin of the catfish (Parasilurus asotus). Comparative Biochemistry and Physiology, $80 B, 475-480$. 
(captions to figures)

Fig. 1. Electrophoresis of purified trypsin from walleye pollock. Electrophoresis was performed using a $0.1 \%$ SDS-12.5\% polyacrylamide slab-gel. Lane 1 contains protein standards; bovine pancreatic trypsinogen (molecular weight, $24 \mathrm{kDa}$ ), bovine milk $\beta$-lactoglobulin $(18.4 \mathrm{kDa})$, and egg-white lysozyme $(14.3 \mathrm{kDa})$. Lane 2 contains walleye pollock trypsin.

Fig. 2. Effect of Calcium ion on the stability of trypsin from walleye pollock. The enzyme was kept at $30{ }^{\circ} \mathrm{C}$ and $\mathrm{pH} 8.0$ for $0-8 \mathrm{~h}$ in the presence of $10 \mathrm{mM} \mathrm{CaCl}_{2}$ (closed symbol) or $10 \mathrm{mM}$ EDTA (open symbol), and then the remaining activities at $30^{\circ} \mathrm{C}$ and $\mathrm{pH} 8.0$ were determined. a: walleye pollock trypsin, b: porcine pancreatic trypsin.

Fig. 3. Effect of $\mathrm{pH}$ on the activity of trypsin from walleye pollock. The activity was determined in $50 \mathrm{mM}$ buffer solutions [acetic acid-sodium acetate $(\mathrm{pH} 4.0-7.0)$, Tris- $\mathrm{HCl}(\mathrm{pH}$ 7.0-9.0), and glycine- $\mathrm{NaOH}(\mathrm{pH} 9.0-11.0)]$ at $37{ }^{\circ} \mathrm{C}$. a: walleye pollock trypsin, b: porcine pancreatic trypsin.

Fig. 4. pH stability of trypsin from walleye pollock. The enzyme was kept at $30{ }^{\circ} \mathrm{C}$ for 30 min and $\mathrm{pH} 4.0-11.0$, and then the remaining activity at $30{ }^{\circ} \mathrm{C}$ and $\mathrm{pH} 8.0$ was determined. a: walleye pollock trypsin, b: porcine pancreatic trypsin. 
Fig. 5. Effect of temperature on the activity of trypsin from walleye pollock. The activity was determined at $\mathrm{pH} 8.0$ and at various temperatures. a: walleye pollock trypsin, b: porcine pancreatic trypsin.

Fig. 6. Thermostability of trypsin from walleye pollock. The enzyme was kept at $20-70{ }^{\circ} \mathrm{C}$ for $15 \mathrm{~min}$ and $\mathrm{pH} 8.0$, and then the remaining activity at $30{ }^{\circ} \mathrm{C}$ and $\mathrm{pH} 8.0$ was determined. a: walleye pollock trypsin, b: porcine pancreatic trypsin.

Fig. 7. Relationship between habitat temperature of fish and thermo stability of the fish trypsin. The $50 \%$ denaturating temperature shows the temperature that the enzyme was denaturated $50 \%$ by incubation at $\mathrm{pH} 8.0$ for $15 \mathrm{~min}$ at a range of $20-70{ }^{\circ} \mathrm{C}$. Open triangle, walleye Pollock trypsin; Closed triangle, brown hakeling trypsin (Kishimura et al., 2006c); Open square, spotted mackerel trypsin (Kishimura et al., 2006b); Closed square, Japanese anchovy trypsin (Kishimura et al., 2005); Open circle, skipjack tuna trypsin (Klomklao et al., 2007); Closed circle, yellowfin tuna trypsin (Klomklao et al., 2006a); Open diamond, porcine pancreatic trypsin. 
Fig. 8. Comparison of the $N$-terminal amino acid sequences of trypsins from walleye pollock ( $T$. chalcogramma) with those of other vertebrates. Cod (Gudmundsdottir et al., 1993); Elkhorn sculpin (Kishimura et al., 2007); Brown hakeling (Kishimura et al., 2006c); Arabesuque greenling (Kishimura et al., 2006a); Spotted mackerel (Kishimura et al., 2006b); Yellow tail (Kishimura et al., 2006c); Jacopever (Kishimura et al., 2007); True sardine (Kishimura et al., 2006a); Japanese anchovy (Kishimura et al., 2005); Skipjack tuna (Klomklao et al., 2007); Tongol tuna (Klomklao et al., 2006b); Yellowfin tuna (Klomklao et al., 2006a); Porcine (Hermodson et al. 1973); Bovine (Walsch, 1970); Human (Emi et al., 1986). Amino acid residues different from the walleye pollock trypsin are shaded. 
Table 1

Purification of trypsin from walleye pollock

\begin{tabular}{lcllll}
\hline $\begin{array}{l}\text { Purification } \\
\text { stages }\end{array}$ & $\begin{array}{l}\text { Protein } \\
(\mathrm{mg})\end{array}$ & $\begin{array}{l}\text { Total } \\
\text { activity } \\
(\mathrm{U})\end{array}$ & $\begin{array}{l}\text { Specific } \\
\text { activity } \\
(\mathrm{U} / \mathrm{mg})\end{array}$ & $\begin{array}{l}\text { Purity } \\
(\text { fold })\end{array}$ & $\begin{array}{l}\text { Yield } \\
(\%)\end{array}$ \\
\hline Crude enzyme & 8,220 & 4,932 & 0.6 & 1 & 100 \\
Sephacryl S-200 & 219 & 2,321 & 10.6 & 18 & 47 \\
Sephadex G-50 & 28 & 1,400 & 50.0 & 83 & 28 \\
\hline
\end{tabular}


Table 2

Effects of various inhibitors on the activity of trypsin from walleye pollock ${ }^{a}$

\begin{tabular}{|c|c|c|}
\hline Inhibitors & Concentration & $\%$ Inhibition \\
\hline Control & & 0 \\
\hline E-64 & $0.1 \mathrm{mM}$ & 0 \\
\hline$N$-ethylmaleimide & $1 \mathrm{mM}$ & 0 \\
\hline Iodoacetic acid & $1 \mathrm{mM}$ & 0 \\
\hline Soybean trypsin inhibitor & $1 \mathrm{mg} / \mathrm{ml}$ & 91 \\
\hline TLCK & $5 \quad \mathrm{mM}$ & 82 \\
\hline TPCK & $5 \mathrm{mM}$ & 11 \\
\hline Pepstatin A & $0.01 \mathrm{mM}$ & 3 \\
\hline EDTA & $2 \mathrm{mM}$ & 9 \\
\hline
\end{tabular}

${ }^{a}$ The enzyme solution was incubated with the same volume of inhibitor at $25^{\circ} \mathrm{C}$ for 15 min and residual activity was analysed using TAME as a substrate for $20 \mathrm{~min}$ at $\mathrm{pH} 8.0$ and $30{ }^{\circ} \mathrm{C}$. 
Fig.1

$45.0 \mathrm{kDa} \longrightarrow$

$24.0 \mathrm{kDa} \longrightarrow$

$18.4 \mathrm{kDa} \longrightarrow$
$14.3 \mathrm{kDa} \longrightarrow$

12 
Fig.2

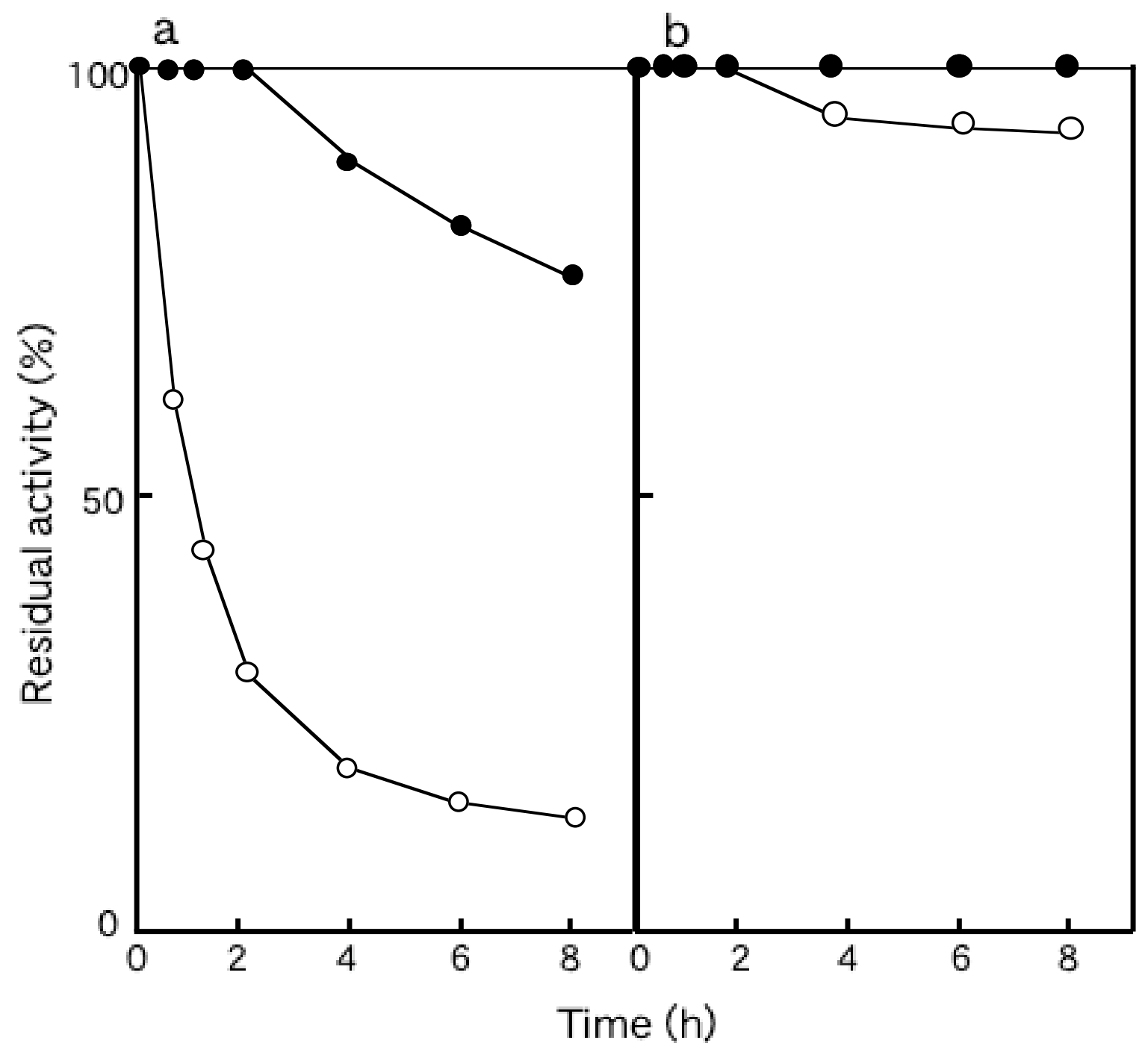


Fig.3

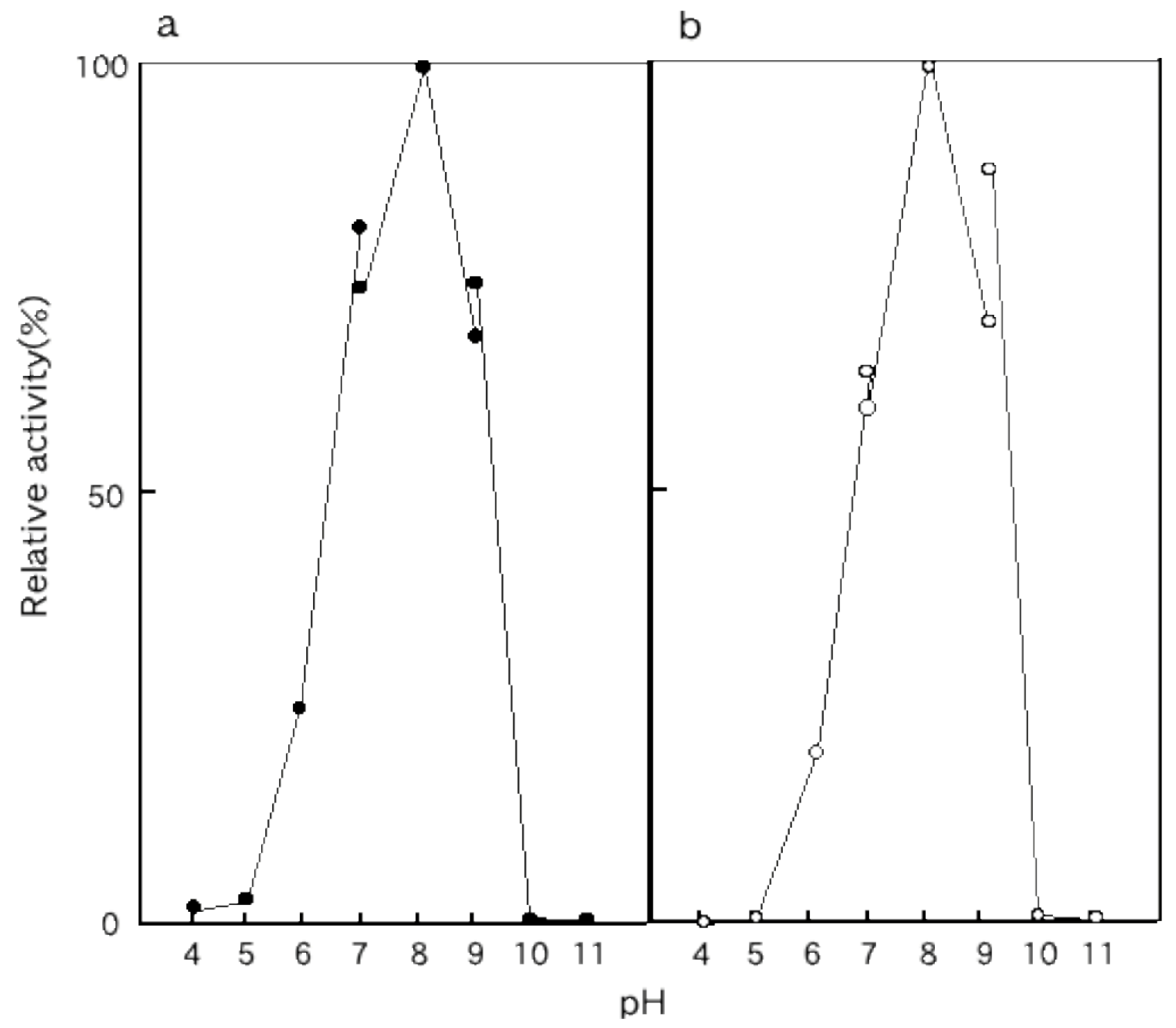


Fig.4

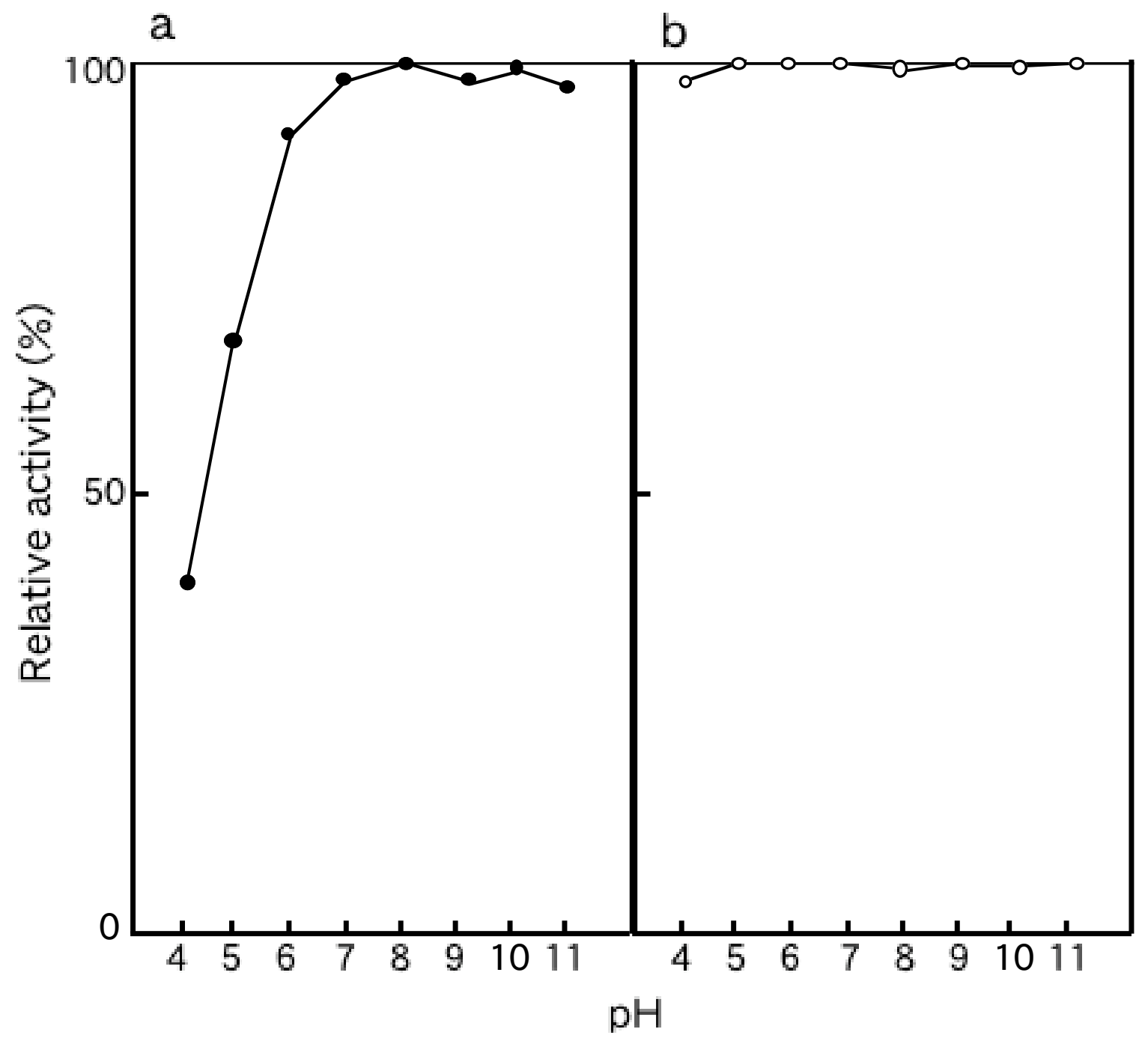


Fig.5

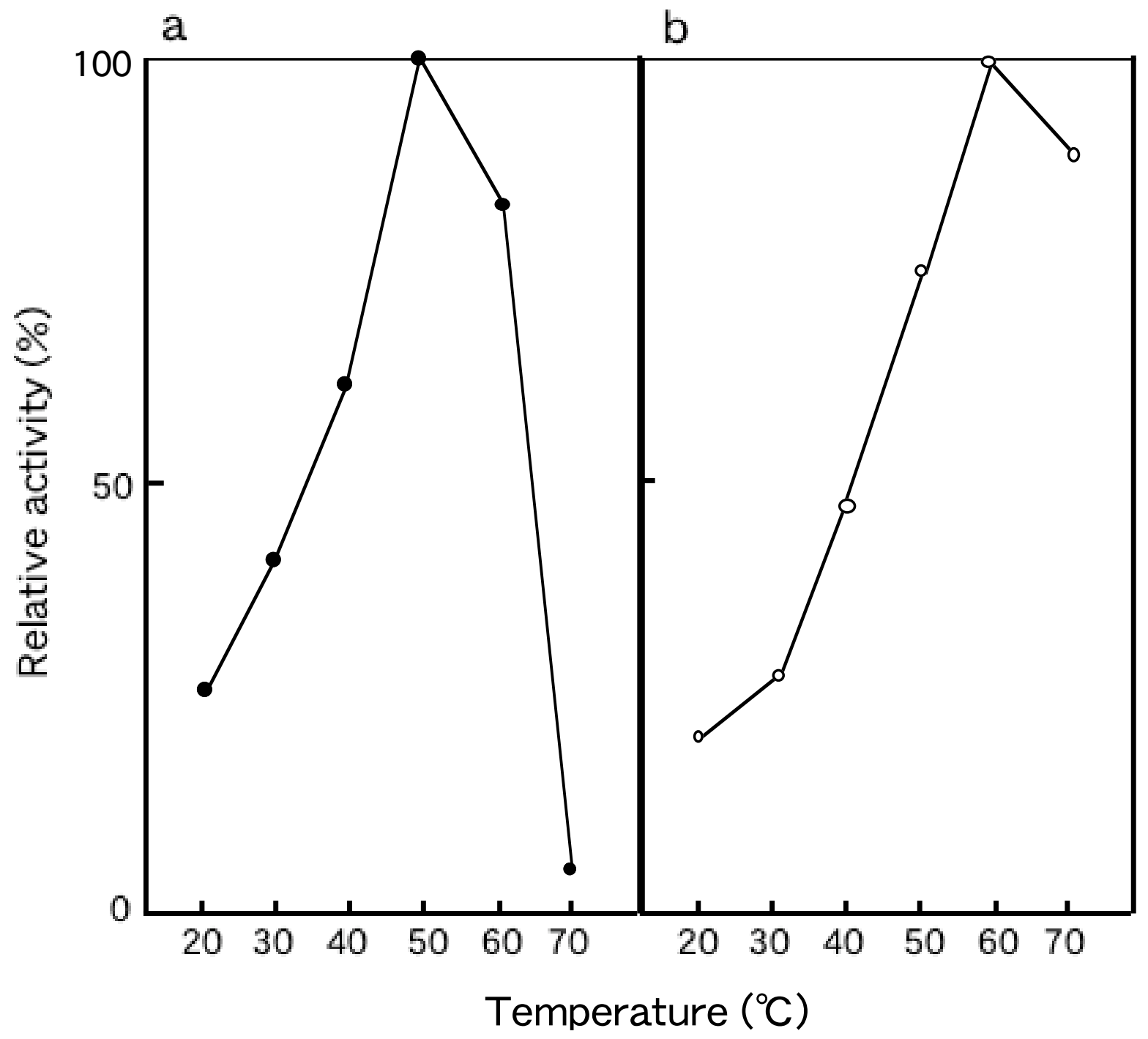


Fig.6

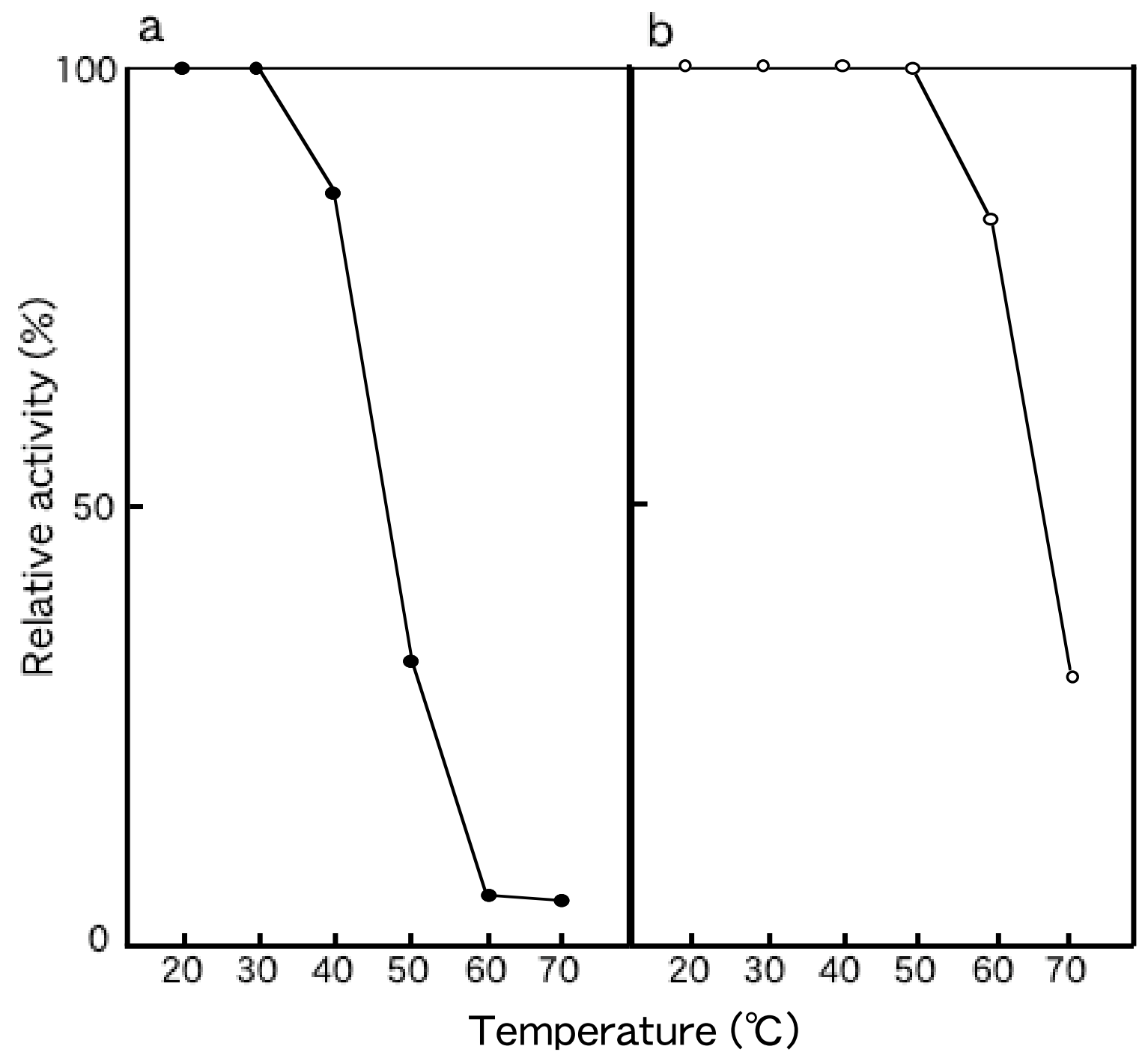


Fig. 7

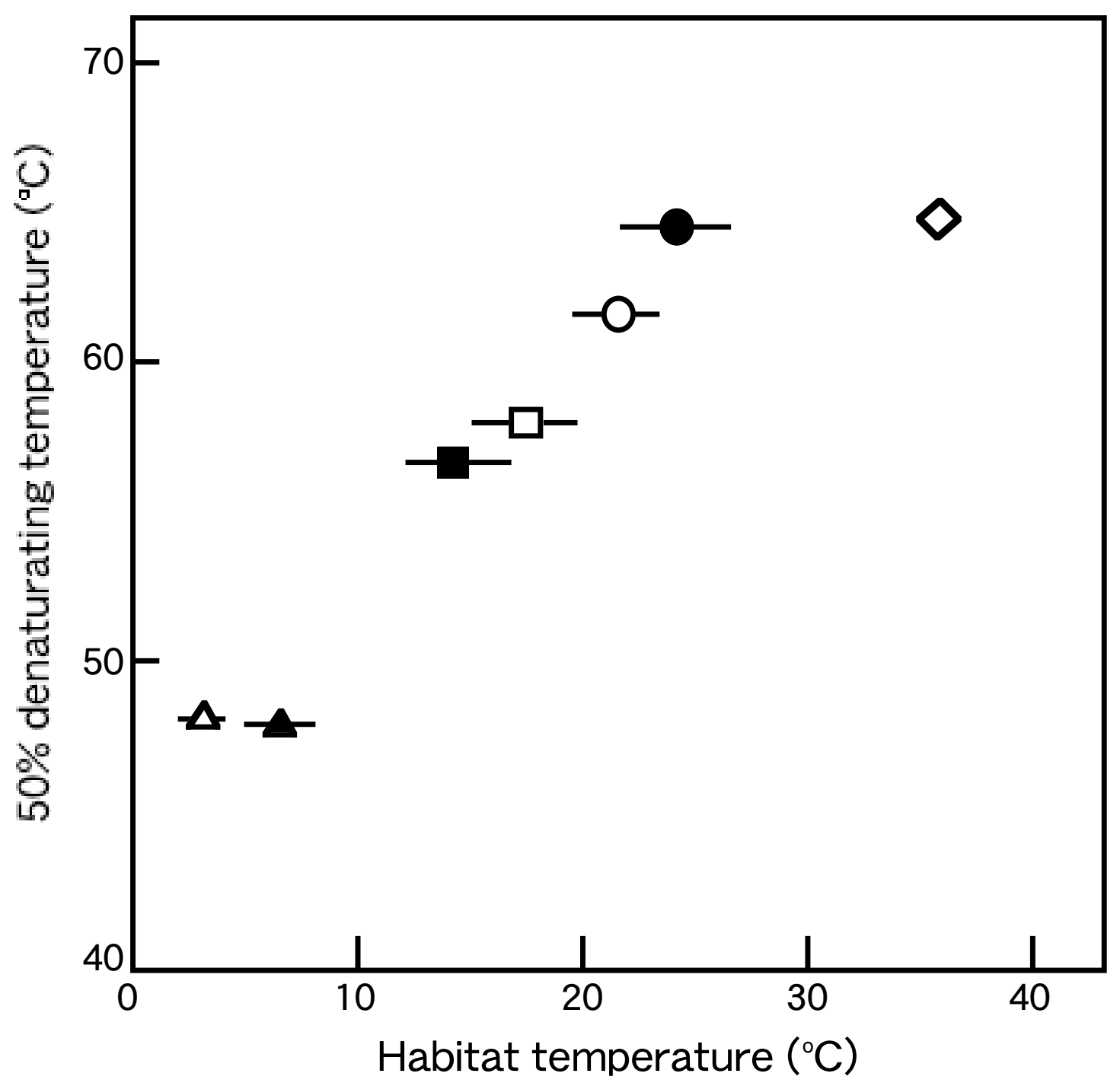


Frigid Zone Fish

Walleye pollok

Cod

Elkhorn sculpin

Brown hakeling

Arabesuque greenling

IVGGYECTKHSQAHQVSLNS IVGGYECTKHSQAHQVSLNS IVGGYECTPHSQAHQVSLNS IVGGYECPKHSQPHQVSLNS IVGGYECTPHTQAHQVSLDS

Temperate Zone Fish

Spotted mackerel

IVGGYECTAHSQPHQVSLNS

Yellow tail

Jacopever

True sardine

Japanese anchovy

IVGGYECTPYSQPHQVSLNS

IVGGYECKPYSQPHQVSLNS

IVGGYECKAYSQPWQVSLNS

IVGGYECQPYSQPHQVSLDS

Tropical Zone Fish

Skipjack tuna

Tongol tuna

Yellowfin tuna

IVGGYECQAHSQPHQVSLNS IVGGYECQAHSQPHQVSLNA IVGGYECQAHSQPPQVSLNA

Mammal

Porcine

Bovine

Human

IVGGYTCAANSVPYQVSLNS IVGGYTCGANTVPYQVSLNS IVGGYNCEENSVPYQVSLNS 